\title{
GOSPODARSTWO RODZINNE JAKO PODSTAWA USTROJU ROLNEGO W ŚWIETLE KONSTYTUCJI RP Z 1997 ROKU
}

\section{FAMILY HOMESTEAD AS THE FOUNDATION OF THE AGRARIAN SYSTEM IN THE LIGHT OF THE CONSTITUTION OF 1997}

\section{STRESZCZENIE}

Zgodnie z art. 23 Konstytucji z 1997 r. podstawą ustroju rolnego państwa polskiego jest gospodarstwo rodzinne. Szczególne wyróżnienie $\mathrm{w}$ świetle zasad ustroju RP gospodarstwa rolnego w postaci go-

" Prof. dr hab., kierownik Katedry Prawa Ochrony Środowiska na Wydziale Prawa i Administracji Uniwersytetu Mikołaja Kopernika.

** Dr hab., prof. UMK, Katedra Prawa Konstytucyjnego na Wydziale Prawa i Administracji Uniwersytetu Mikołaja Kopernika. 
spodarstwa rodzinnego wynika ze ścisłego połączenia gospodarstwa rolnego z gospodarstwem domowym. Analiza art. 23 Konstytucji ma na celu ustalenie aktualnych kierunków kształtowania ustroju rolnego Polski. Z jednej strony kierunki te wynikają z założeń „społecznej gospodarki rynkowej", zaś z drugiej z rosnących wyzwań związanych $\mathrm{z}$ ochroną środowiska (m.in. rolnictwo ekologiczne, ochrona środowiska przed skutkami stosowanych procesów w produkcji rolnej, wymagania weterynaryjne dla ochrony zdrowia zwierząt). Obecne rozwiązania w tym przedmiocie powinny zostać dostosowane do aktualnych warunków społeczno-gospodarczych.

\section{Słowa kluczowe}

Gospodarstwo rodzinne; ustrój rolny; rolnictwo i ochrona środowiska.

\section{ABSTRACT}

According to Article 23 of the Constitution of 1997 family homestead is the foundation of the Polish agrarian system. Its special status in the Polish legal system stems from the closest connection between homestead and household. The Analysis of Article 23 reveals current tendencies of the Polish agrarian system. Firstly, those tendencies are the consequences of the "social market economy" concept. Secondly, they result from the growing challenges posed by the environmental protection (ecological farming; protection of the environment from the negative impact of the farming production processes; veterinary protection of animals' health). Present regulations concerning this subject should be adjusted to the current socio-economic conditions.

\section{Keywords}

Family homestead; agrarian system; farming and environmental protection.

Niedawno minęła 25. rocznica zmian ustrojowych w Polsce. Przemiany, które wówczas nastąpiły miały doniosłe znaczenie. Dotyczyły one praktycznie wszystkich sfer życia społecznego. Wydaje się, że niektóre $\mathrm{z}$ nich z perspektywy ćwierćwiecza wymagają korekt, niekiedy nawet znacznych. Przykładem może być kwestia ustroju rolnego, znajdującego swoje odzwierciedle- 
nie w warstwie normatywnej Konstytucji RP z 1997 r. ${ }^{1}$ Zgodnie z art. 23 ustawy zasadniczej podstawą ustroju rolnego państwa jest gospodarstwo rodzinne. Zasada ta nie narusza postanowień art. 21 i art. 22. Niniejszy tekst dotyczy tej właśnie wartości, sposobu jej ukształtowania w Konstytucji RP z 1997 r. oraz kierunków przyszłej regulacji prawnej ${ }^{2}$ wcielającej interesującą nas wartość w życie, a dostosowującej ją do aktualnych warunków społecznych.

Kwestia ustroju rolnego nie doczekała się kompleksowej regulacji. Jest to poważny mankament dostrzegalny w doktrynie $^{3}$. Wynikają bowiem z tego faktu różnego rodzaju problemy, zwłaszcza kwalifikacyjne w zakresie działalności rolniczej z uwagi na podmiot prowadzący gospodarstwo rolne. Niemniej jednak Konstytucja RP zawiera minimalną treść zakreślającą kształt ustroju rolnego i pozostawia rozwinięcie jej w gestii ustawodawcy zgodnie z duchem ustawy zasadniczej oraz zamysłem jej twórców.

Regulacja konstytucyjna dotycząca ustroju rolnego państwa stanowi dopełnienie i konkretyzację zasady społecznej gospodarki rynkowej nie zaś wyjątek od niej ${ }^{4}$ W ramach ustroju społeczno-gospodarczego wyróżnić należy ustrój rolny, którego podstawę stanowią gospodarstwa rodzinne ${ }^{5}$. Kategorie te

1 Dz.U. z 1997 r. Nr 78, poz. 483 ze zm.

2 Obecnie na ukończeniu jest postępowanie ustawodawcze w Sejmie dotyczące poselskiego projektu ustawy o kształtowaniu ustroju rolnego oraz o zmianie niektórych innych ustaw (druk nr 3109). Ustawa uchwalona dnia 5 sierpnia 2015 r. miałaby wejść w życie po podpisaniu przez prezydenta z dniem 1 stycznia 2016 r. Zgodnie z opiniami przygotowanymi na zlecenie Biura Analiz Sejmowych w trakcie postępowania ustawodawczego przyjęte w projekcie rozwiązania dotyczące gospodarstw rodzinnych nie odpowiadają założeniom konstytucyjnym oraz obecnym warunkom społecznym i gospodarczym w tym zakresie.

3 Por. A. Lichorowicz, Status prawny gospodarstw rodzinnych $w$ ustawodawstwie krajów Europy Zachodniej, Białystok 2000, s. 13; A. Pawłowski, Aspekty podmiotowe i przedmiotowe ustroju rolnego, „Gdańskie Studia Prawnicze" 2014, t. XXXI, s. 1091-1104.

4 Por. L. Garlicki, Art. 23, w: Konstytucja Rzeczypospolitej Polskiej. Komentarz, t. 4, red. L. Garlicki, Warszawa 2005, s. 3.

5 Por. A. Domańska, Konstytucyjne podstawy ustroju gospodarczego Polski, Warszawa 2001, s. 137. 
powinny być zatem interpretowane $\mathrm{w}$ odpowiedniej korelacji prowadzącej do ustalenia spójnych kategorii łączących wartości ustroju gospodarczego i ustroju rolnego RP. Potwierdzeniem tej tezy jest poniekąd zdanie Trybunału Konstytucyjnego wyrażone w Wyroku z dnia 7 maja 2014 r. (K 43/12). Organ ten słusznie zauważył, że art. 20 ustawy zasadniczej nie definiuje „społecznej gospodarki rynkowej", lecz odsyła do jej koncepcji wypracowanej we współczesnej myśli społecznej z uwzględnieniem naturalnej konieczności jej modyfikacji pod wpływem zmieniających się warunków. Niektóre z komponentów społecznej gospodarki rynkowej są jednak wprost wyrażone w omawianym przepisie i wyznaczają normatywną treść tego pojęcia. Chodzi o wolność działalności gospodarczej, własność prywatną oraz solidarność, dialog, a także współpracę partnerów społecznych. Treść pojęcia „społeczna gospodarka rynkowa” współwyznaczają też, choć pośrednio, art. 21 Konstytucji RP precyzujący pojęcie prawa własności, art. 22 wyznaczający zakres wolności działalności gospodarczej, art. 23 określający swoiste cechy ustroju gospodarczego w rolnictwie i art. 24 wyrażający zasadę ochrony pracy. Należy zaznaczyć ponadto, że społeczna gospodarka rynkowa jest koncepcją ładu gospodarczego, ale też społecznego zarazem. Komponent gospodarczy łączy się w niej bowiem ze społecznym. Są one względem siebie komplementarne, jak również wzajemne się warunkują. Zgodnie z tym wzorcem gospodarka, choć rynkowa, ma wyraźne cele społeczne, takie jak: zrównoważony rozwój, wysoki poziom zatrudnienia, godność pracy, odpowiedni system ubezpieczenia społecznego, a także ochronę środowiska, zapewnienie energii, transport ${ }^{6} . \mathrm{W}$ interesującym nas zakresie należy także dodać wartość w postaci rodzinnych gospodarstw rolnych. Osiąganie tych celów jest jednak uwarunkowane wydolnością gospodarki. Stąd też należy uwzględnić rolę państwa nie tylko jako arbitra, lecz także jako podmiotu współuczestniczącego w gospodarowaniu i realizo-

6 Por. K. Strzyczkowski, Konstytucyjna zasada społecznej gospodarki rynkowej jako podstawa tworzenia i stosowania prawa, w: Zasady ustroju społecznego i gospodarczego $w$ procesie stosowania Konstytucji, red. C. Kosikowski, Warszawa 2005, s. 12-13. 
waniu polityki społecznej, a to może wymagać ingerowania $\mathrm{w}$ proces gospodarczy. Ingerencja ta powinna między innymi polegać na stosowaniu preferencji i ochrony względem wartości szczególnie wyróżnianych w Konstytucji. W świetle art. 23 ustawy zasadniczej jest nią gospodarstwo rodzinne w ramach ustroju rolnego RP.

Literalna wykładnia art. 23 Konstytucji RP wskazuje dwie relewantne kategorie $\mathrm{w}$ postaci wskazanego ustroju rolnego państwa oraz gospodarstwa rodzinnego. Zauważa się w doktrynie, że przepis ten nie stanowi całościowej regulacji ustroju rolnego RP i powinien być traktowany jako deklaracja w zakresie ustawowego regulowania tego ustroju ${ }^{7}$. Można także przyjmować, iż w tym zakresie mamy do czynienia z normą programową ustawy zasadniczej ${ }^{8}$. Ustawodawca, kierując się założeniami konstytucyjnymi, powinien uregulować ustrój rolny. Założeń tych zidentyfikowano kilka. Przede wszystkim, pod względem ilościowym, obszarowym, produkcyjnym, gospodarstwa rodzinne powinny stanowić trzon podmiotów prowadzących produkcję rolną. Ponadto państwo powinno udzielać należytego wsparcia temu rodzajowi gospodarstw, w tym także wsparcia o charakterze ochronnym. Artykuł 23 Konstytucji RP w sposób wiążący wyznacza tak określony cel działań ustawodawcy. Ustawodawca powinien kierować się tym właśnie celem.

Nie ulega wątpliwości, że w ramach ustroju rolnego podstawową jednostką produkcyjną w zakresie rolnictwa jest gospodarstwo rolne9. Przy czym w świetle zasad ustroju RP wyróżnione zostało szczególne gospodarstwo rolne w postaci gospodarstwa rodzinnego. Powstaje ono ze ścisłego połączenia gospodarstwa rolnego z gospodarstwem domowym. Konstytucja nie definiuje kategorii gospodarstwa rodzinnego. Niemniej jednak przyjmuje się, że o rodzinnym charakterze świadczy

7 Por. A. Lichorowicz, Konstytucyjne podstawy ustroju rolnego Rzeczypospolitej $w$ świetle artykułu 23 Konstytucji, w: Konstytucyjne podstawy systemu źródeł prawa, red. M. Wyrzykowski, Warszawa 2001, s. 114-115.

8 Por. J. Boć, Konstytucje Rzeczypospolitej oraz komentarz do Konstytucji $R P$ z 1997 roku, Wrocław 1998, s. 60.

9 Szczegółowa analiza uwzględniająca stan nauki por. A. Domańska, op. cit., s. 137-138. 
zaangażowanie $\mathrm{w}$ pracę ze strony rodziny $\mathrm{w}$ gospodarstwie rolnym oraz współzależność rozwoju rodziny i gospodarstwa. Gospodarstwo rodzinne rozumiane jest jako gospodarstwo zapewniające utrzymanie rodzinie rolnika ${ }^{10}$. Nie może być więc zbyt małe. Jego wielkość musi być także dostosowana do możliwości zapewnienia w nim fizycznej pracy właścicielowi, a także jego rodzinie, ewentualnie z pomocą pracowników najemnych. Istotne są także możliwości technologiczne oraz wyposażenie techniczne. Regulacja konstytucyjna uzasadnia preferencje w rozwiązaniach ustawowych na rzecz gospodarstw rodzinnych w celu zapewnienia, aby ich działalność stanowiła podstawę ustroju rolnego.

W ramach ustroju rolnego dopuszczalna jest zatem działalność rolna innych niż rodzinne form gospodarstw rolnych prowadzonych zwłaszcza przez podmioty niebędące osobami fizycznymi oraz przez rolników, których działalność opiera się na pracy najemnej. Taka konstatacja jest następstwem uwzględnienia w interpretacji art. 23 Konstytucji RP także kategorii wolności działalności gospodarczej i ochrony własności. Niemniej jednak szczególna pozycja gospodarstw rodzinnych w ramach ustroju rolnego nakazuje ustawodawcy kształtowanie systemu w oparciu o preferencje na rzecz gospodarstw rodzinnych.

Pamiętać także trzeba, że działalność rolnicza prowadzona przez gospodarstwa rodzinne nie może być pojmowana jako ograniczająca się do zaspokojenia potrzeb wyłącznie rolnika i jego rodziny. Ustrój rolny należy bowiem postrzegać także w kontekście dobra wspólnego, a zatem gospodarstwo rodzinne to takie gospodarstwo, które w ramach ustroju rolnego zaspakaja również potrzeby żywnościowe społeczeństwa. Tu jednak pojawia się problem, wiążący się z tym, że zbywając produkty (niezależnie od ich klasyfikacji prawnej - pożytki, zwierzęta, rośliny, produkty rolnictwa ekologicznego) gospodarstwo rodzinne albo też jego członkowie stają się uczestnikami rynku, gdzie dominuje zasada wolności działalności gospodarczej oraz prawa ekonomii (popyt i podaż), a tym samym zbliżają się już

10 Por. P. Winczorek, Komentarz do Konstytucji Rzeczypospolitej Polskiej z dnia 2 kwietnia 1997 r., Warszawa 2000, s. 36. 
do tych standardów, które prawodawca stawia właśnie prowadzeniu działalności gospodarczej. Jednak sam ustawodawca zakłada, iż gospodarstwo rodzinne będzie na tyle wydolne, aby utrzymać jego członków i inne osoby nieuczestniczące w procesie produkcji rolnej.

Ustrojodawca w momencie tworzenia ustawy zasadniczej wybrał rodzinny model gospodarstwa rolnego ${ }^{11}$. Wskazuje się w doktrynie, że tego typu gospodarstwa odporne są na fluktuacje cen na rynku i zdolne są do przetrwania okresów kryzysowych bez pomocy z zewnątrz (np. z budżetu państwa). Produkcja ich jest bardziej elastyczna, zgodna z ochroną środowiska. Gospodarstwa tego typu nie mają charakteru anonimowej produkcji, wyzwalają indywidualne inicjatywy ludzkie, osoby w nich pracujące zwiększają swoje zaangażowanie życiowe w rolnictwie oraz poczucie odpowiedzialności za gospodarstwo, jego produkcję. Przyczyniają się one do utrzymania elementów narodowych w gospodarce danego kraju. Wszystkie te kategorie wraz z argumentem ekonomicznym sprawiają, iż gospodarstwo rodzinne czy ustrój rolny są niezwykle ważnymi sferami egzystencji państwa.

Oceniając jednak praktyczne zastosowanie wskazywanych wyżej cech gospodarstwa rodzinnego, należy podkreślić wyjątkowo małe zainteresowanie prowadzeniem rolnictwa ekologicznego. Zarówno prawodawca polski, jak i prawodawca europejski dostrzegli związek pomiędzy produkcją rolną, a ochroną środowiska. Związek ten przejawia się jednak w dwóch kierunkach - po pierwsze produkcja zdrowej żywności, za pomocą naturalnych metod, po drugie ochrona środowiska przed wpływem wywołanym stosowanymi procesami w produkcji rolnej (np. odprowadzanie ścieków $)^{12}$. Jeśli już wskazuje się na uwzględnianie w gospodarstwie rodzinnym ochrony środowiska, to $\mathrm{z}$ reguły $\mathrm{w}$ tym pierwszym wymiarze, związanym z powstawaniem pro-

11 Por. A. Lichorowicz, Status prawny..., s. 12-13.

12 Zob. B. Rakoczy, Problemy ochrony środowiska $w$ procesie produkcji rolnej, „Prawo i środowisko” 2002, nr 4, s. 111-117; Idem, Ochrona środowiska $w$ procesie produkcji rolnej, w: Prawo rolne, red. A. Stelmachowski, Warszawa 2009, s. 357-369. 
duktów. Natomiast wymogi związane z ochroną środowiska traktowane są w kategoriach zbędnych utrudnień i przeszkód stawianych gospodarstwu rodzinnemu oraz jego członkom. Dostrzec jednak można zmieniającą się świadomość członków gospodarstw rodzinnych w kierunku zwiększenia potrzeby zmiany nastawienia do wymogów związanych z ochroną środowiska.

Innym problemem, pomimo wyżej wymienionych pozytywów gospodarstw rodzinnych, jest zachowywanie standardów wynikających z przepisów prawa weterynaryjnego ${ }^{13}$. Również w tym obszarze wymogi, szczególnie wynikające z prawa europejskiego, są oceniane zasadniczo jako zbędne, niepotrzebne, utrudniające sam proces produkcji rolnej, a - co chyba ma znaczenie najistotniejsze - zapewnienie tych standardów jest kosztochłonne.

O szczególnym statusie gospodarstwa rodzinnego wypowiedział się Trybunał Konstytucyjny w Wyroku z dnia 31 stycznia 2001 r. (P 4/99) i potwierdził swoje stanowisko w Wyroku z dnia 5 września 2007 r. (P 21/06). Organ ten ustalił, że art. 23 Konstytucji RP wprowadza konstytucyjną odrębność gospodarstwa rolnego jako składnika majątku. Przepis ten formułuje koncepcję gospodarstwa rodzinnego jako wytyczną dla organów władzy państwowej. Uzasadnia on odwołanie się do koncepcji rodzinnego gospodarstwa rolnego jako wartości konstytucyjnej, która umożliwia traktowanie tak opisanego gospodarstwa w sposób szczególny. Niewątpliwe jest jednak powiązanie art. 23 ze wskazanymi w nim normami konstytucyjnymi, a także innymi kategoriami podlegającymi konstytucyjnej ochronie. We wskazanych wyrokach Trybunał odniósł się do szczegółowej kategorii dziedziczenia. W odniesieniu do tej kwestii w zakresie gospodarstw rolnych TK wskazał, że art. 23 zdanie 2 Konstytucji RP wyraża zakaz eliminacji instytucji dziedziczenia lub wprowadzenia takich rozwiązań, które wykluczałyby swobodę testowania lub równą ochronę praw wszystkich

13 Nie rozwijamy tego wątku w tym artykule, gdyż wykraczałoby to poza ramy opracowania. Pojęcie prawo weterynaryjne użyte jest w znaczeniu, jakie nadał tej dziedzinie spraw M. Rudy. Zob. M. Rudy, Wstęp do prawa sanitarnego i weterynaryjnego, Wrocław 2010. 
spadkobierców. Nie wyłącza on natomiast wprowadzenia co do spadku, w skład którego wchodzi gospodarstwo rolne, szczególnej regulacji modyfikującej w określonych punktach ogólne przepisy prawa spadkowego. Modyfikacje te nie mogą być dowolne, ale służyć mają praktycznej realizacji wyrażonej w art. 23 zasady, zgodnie z nią gospodarstwo rodzinne jest podstawą ustroju rolnego państwa. Oczywiste przy tym jest, że gospodarstwo rodzinne nie jest celem samym w sobie. $\mathrm{Z}$ wymienionego przepisu Konstytucji RP wynika, iż powinno ono stanowić efektywną formę gospodarowania, pozwalającą prowadzić produkcję rolną w celu nie tylko zapewnienia „godziwego" utrzymania rodzinom rolniczym, ale także najpełniejszego zaspokojenia potrzeb społeczeństwa. Tylko bowiem tak prowadzone gospodarstwo może stanowić podstawę ustroju rolnego państwa. Artykuł 23 Konstytucji RP daje podstawę do przyjęcia przez ustawodawcę uregulowań szczególnych dotyczących dziedziczenia gospodarstw rolnych także z uwagi na fakt, że inne dyrektywy konstytucyjne, a zwłaszcza wynikające z nakazu ochrony prawa dziedziczenia, nie są w tym przypadku jednoznaczne. Uzasadnia to pewien stopień swobody ustawodawcy, który realizując minimalne wymagania ochrony prawa dziedziczenia - może wprowadzić rozwiązania służące innym wartościom konstytucyjnym. Do Trybunału Konstytucyjnego należy ocena, czy normy ustawowe, określające sposób i zakres realizacji w takiej sytuacji kilku różnych wartości konstytucyjnych, pozostają w zgodzie z ustawą zasadniczą.

Następnie Trybunał wskazał, że prowadzenie gospodarstwa rolnego może być traktowane jako szczególny rodzaj działalności gospodarczej, a samo gospodarstwo rolne uznawane być może za rodzaj przedsiębiorstwa. Zgodnie z art. 22 Konstytucji RP możliwe jest ograniczenie wolności działalności gospodarczej ze względu na ważny interes publiczny. Jednym z przejawów tak opisanego interesu jest konstytucyjna ochrona gospodarstw rodzinnych będących podstawą ustroju rolnego RP. Trzeba przyjąć, iż w przypadku dziedziczenia przedsiębiorstw interes publiczny, o którym mowa w art. 22 Konstytucji, może przemawiać za tym, aby w pewnych sytuacjach pozostawały one w niepodzielnym władaniu jednej tylko osoby. Łączy się to 
z dyrektywą wynikającą z art. 23 Konstytucji przy założeniu, że gospodarstwo rolne jest szczególnym przedmiotem własności, a władze publiczne mają obowiązek podejmowania działań, aby jego prowadzenie było „produktywną” formą gospodarowania. Dlatego, zdaniem Trybunału Konstytucyjnego, także art. 22 i 23 Konstytucji dają pewną podstawę do odrębnego uregulowania spraw spadkowych dotyczących gospodarstw rolnych. Rzecz jasna regulacja ta powinna być skorelowana z całokształtem regulacji dotyczącej obrotu gruntami rolnymi.

Uprawniony jest więc wniosek, że ochrona gospodarstw rodzinnych w kontekście innego rodzaju działalności rolnej połączona jest z interesem publicznym. Przejawia się on przynajmniej w kilku kategoriach. Przede wszystkim jest to ochrona rodziny, która prowadząc gospodarstwo rolne zapewnia utrzymanie członkom własnej wspólnoty. Ma to przełożenie także na kategorię pomocniczości nakazującej umacniać uprawnienia jednostek i ich wspólnot. Rodzina jest bowiem podstawową wspólnotą jednoczącą jednostki. W pierwszej kolejności zatem rodzina powinna zapewniać funkcjonowanie jednostek. W dalszej kolejności przekłada się to na ochronę równowagi budżetowej, gdyż gospodarstwo rodzinne zapewniające byt swoim członkom nie potrzebuje wsparcia ze strony państwa, zwłaszcza, gdy jest ono „produktywne”. Równowaga budżetowa czy sam budżet państwa są elementami wchodzącymi w skład kategorii dobra wspólnego utożsamianego niejednokrotnie przez TK z interesem publicznym. Niewątpliwie dobro wspólne - Rzeczpospolita Polska to także określona struktura gospodarcza kraju, a w tym odpowiednia struktura własności nieruchomości oraz równych uprawnień do jej nabywania. Wszystkie te wartości muszą zostać skorelowane w taki sposób, aby wykonanie normy zakodowanej w art. 23 Konstytucji RP było realne. Parafrazując zdanie TK, należy stwierdzić, że art. 22 i 23 Konstytucji RP dają pewną podstawę do odrębnego uregulowania obrotu gruntami rolnymi czy działalności rolniczej w odniesieniu do gospodarstw rodzinnych.

Podzielić należy stanowisko, zgodnie z którym do kategorii gospodarstwa rodzinnego zaliczyć można także gospodarstwa rolne, gdzie obszar użytków rolnych przekracza 300 ha, o ile go- 
spodarstwo to jest prowadzone „rodzinnie"14. W eksponowaniu więzów rodzinnych przejawia się podstawowe założenie aksjologiczne art. 23 Konstytucji RP. Prawodawca stara się bowiem łączyć ze sobą znaczenie gospodarczej jednostki, zapewniającej prowadzenie gospodarki rolnej z więzami osobistymi członków tej jednostki, pracującej na jej rzecz. Eksponowanie osobistych związków w ramach jednostek organizacyjnych przejawia się chociażby w konstrukcji spółek osobowych, w której - jak zauważa się w piśmiennictwie - struktura osobowa ma istotne znaczenie $^{15}$. Zatem eksponowanie więzów osobistych pomiędzy członkami takich jednostek nie jest zastrzeżona jedynie dla gospodarstw rodzinnych. Jednak charakter tych więzi jest inny, co uzasadnia odrębne traktowanie owych gospodarstw rodzinnych. Przede wszystkim ustawodawca konstytucyjny wskazuje nie na jakiekolwiek więzi łączące członków takiej jednostki organizacyjnej, ale wyraźnie odnosi się do jednej kategorii więzi - więzi rodzinnych. W tym zakresie chodzi o więzi oparte na najdalej idącym ich osobistym charakterze, wzajemnym zaufaniu, wsparciu, pomocy. Nie bez znaczenia jest także wspólne pozyskiwanie środków do utrzymywania się członków gospodarstwa rodzinnego. Tymczasem więź wspólników spółek osobowych nie wymaga aż tak daleko idącej bliskości emocjonalnej i co najwyżej jest to wspólność interesów ekonomicznych ${ }^{16}$.

Z drugiej jednak strony konstrukcja ustroju rolnego, u podstaw której leży pojęcie gospodarstwa rodzinnego coraz trudniej opiera się gospodarczym, a także ekonomicznym realiom. Stąd też prawodawca zwykły co rusz boryka się z problemem zakwalifikowania gospodarstwa rodzinnego i jego członków, biorąc pod uwagę potrzeby oraz standardy prawa podatkowego, cywil-

14 Por. J. Galster, T. Staranowicz, Konstytucyjne pojęcie rodzinnego gospodarstwa rolnego i jego ustawowa deformacja. Studium jednego przypadku, „Journal of Modern Science” 2012, vol. 13, nr 2, s. 87.

15 A. Kidyba, Handlowe spótki osobowe, Warszawa 2013; Prawo spótek, red. A. Kidyba, Warszawa 2014.

16 Oczywiście nie można wykluczyć również i bliskich relacji wspólników, a nawet rodzinnych, ale nie mają one wpływu na sam charakter prawny spółki osobowej. 
nego czy wreszcie prawa gospodarczego publicznego ${ }^{17}$. Stąd też w piśmiennictwie poszukuje się usilnie rozwiązań normatywnych, umożliwiających pogodzenie ze sobą tradycyjnego ujęcia gospodarstwa rolnego silnie powiązanego z więzami rodzinnymi, z wymogami współczesnej gospodarki i ekonomii. Badająca ten problem D. Łobos-Kotowska wskazuje, iż konieczna jest redefinicja gospodarstwa rodzinnego, uwzględniająca po pierwsze dopuszczalność jego prowadzenia w dowolnej formie cywilnoprawnej, poczynając od jednoosobowo prowadzonej działalności gospodarczej, a kończąc na spółkach prawa handlowego, po drugie otwartość składu osobowego, który może wykraczać poza rolnika, małżonka rolnika czy domownika, z tym zastrzeżeniem poczynionym przez tę Autorkę, że skład sił najemnych nie może przekroczyć 50\% członków rodziny, po trzecie rezygnację z norm obszarowych z wyjątkiem norm minimalnych, po czwarte zmianę oceny rozmiaru gospodarstwa z norm obszarowych na standardy dochodowe, po piąte wzmocnienie znaczenia zysku w funkcjonowaniu takiego gospodarstwa, wreszcie po szóste prowadzenie gospodarstwa rodzinnego w oparciu o składniki majątkowe dwóch lub więcej gospodarstw rolnych $\mathrm{w}$ ujęciu ekonomicznym ${ }^{18}$. Autorka postuluje, aby gospodarstwo rodzinne pojmować jako zespół składników majątkowych, stanowiących zorganizowaną całość gospodarczą, objętych pojęciem gospodarstwa rolnego $\mathrm{z}$ art. $55^{3}$ k.c. ${ }^{19}$, któremu można przydać cechę rodzinności. Owa cecha rodzinności, według D. Łobos-Kotowskiej, powinna następować z zastosowaniem kryteriów rodziny określonych $\mathrm{w}$ prawie rodzinnym i opiekuńczym, przy czym ich dopełnieniem jest substrat osobowy, obejmujący rodzinny krąg osób związanych czynnikiem pracy $\mathrm{z}$ tym gospodarstwem rolnym ${ }^{20}$. Pogląd ten zasadniczo trafnie

17 Por. B. Rakoczy, Publiczne prawo gospodarki rolnej i przetwórczej, w: Publiczne prawo gospodarcze, red. A. Powałowski, Warszawa 2012, s. 135-161.

18 Por. D. Łobos-Kotowska, Gospodarstwo rodzinne. Prawne formy organizacji, Sosnowiec 2006, s. 49-50.

19 Ustawa z dnia 23 kwietnia 1964 r. Kodeks cywilny, t.j. Dz.U. z 2014 r., poz. 121 ze zm.

20 Ibidem, s. 50. 
diagnozuje kierunki, w których powinien zmierzać prawodawca polski. Niemniej jednak nie można go przyjąć bez zastrzeżeń.

Wątpić należy w możliwość prowadzenia gospodarstwa rodzinnego przez kapitałową spółkę handlową, która jest kapitałowo, personalnie kontrolowana przez jedną rodzinę (kilka osób powiązanych relacjami pokrewieństwa lub powinowactwa). Stosowanie preferencji względem podmiotów rodzinnych powinno mieć swoje racjonalne wyjaśnienie i nie powinno rozciągać się na inne podmioty prowadzące działalność rolniczą. Gospodarstwo rodzinne pełni bowiem, obok innych, funkcję socjalną. Jest ona powiązana z systemem ulg, ale także preferencji gospodarczych ${ }^{21}$. Jako nieakceptowane podaje się korzystanie z tego typu preferencji przez podmioty nie prowadzące gospodarstw rodzinnych.

Poza tym należy uwzględniać, iż w przypadku kapitałowych spółek handlowych więzy osobiste pomiędzy wspólnikami nie mają żadnego znaczenia. Akcentując rodzinny charakter gospodarstwa prawodawca ma na względzie pierwotne związki pomiędzy osobami w nim pracującymi, a nie wtórne. W przypadku kapitałowej spółki handlowej za podstawowe należy uznać więzi korporacyjne, a nie rodzinne. Stąd też przy dopuszczeniu takiej formy organizacyjnoprawnej mielibyśmy do czynienia z zepchnięciem więzów rodzinnych na plan dalszy, kosztem więzów korporacyjnych.

Odrębnym problemem pozostaje dopuszczalność prowadzenia gospodarstwa rodzinnego w formie osobowej spółki handlowej czy nawet spółki cywilnej. Cytowana wyżej D. Łobos-Kotowska, dostrzegając i zalety, i wady takich rozwiązań, ostatecznie opowiada się za dopuszczalnością prowadzenia gospodarstw rodzinnych w formie osobowych spółek handlowych i spółki cywilnej. Choć w tym przypadku skład osobowy wspólników ma większe znaczenie niż w spółkach kapitałowych, to jednak z punktu widzenia aksjologii konstytucyjnej należałoby przyjąć, że - przy dopuszczeniu takich form organizacyjnopraw-

21 Por. B. Jeżyńska, Współczesne funkcje gospodarstw rodzinnych. Zagadnienia prawne, Opinie i Ekspertyzy OE-214, Kancelaria Senatu styczeń 2014, s. $16-17$. 
nych - ograniczeniu musiałaby ulec zmiana składu osobowego spółki, względnie musiałaby być ona powiązana ściśle $\mathrm{z}$ więzami rodzinnymi.

Wskazywane wyżej wątpliwości kierują uwagę na konieczność poszukiwania innych rozwiązań, dających pogodzić się z aksjologią konstytucyjną i realiami gospodarczymi. Tą drogą jest stworzenie nowego modelu (typu) spółki (np. spółki rolnej), która - korzystając z konstrukcji typowych dla spółek opartych na więzach korporacyjnych, ekonomicznych - uwzględniałaby rodzinny charakter więzi. Rozważenia wymagałoby to, czy przyjąć punkt widzenia przedmiotowy i akcentować rodzaj prowadzonej działalności, czy też akcentować przede wszystkim element podmiotowy - skład osobowy. Obecny model konstytucyjny próbuje łączyć elementy podmiotowe (rodzinne) z elementami przedmiotowymi (gospodarstwo), co wydaje się być w ustawodawstwie zwykłym coraz trudniejsze do utrzymania. Można tu skorzystać z wzorów funkcjonujących w innych państwach europejskich ${ }^{22}$.

Zgodnie z brzmieniem art. 23 Konstytucji RP podstawą ustroju rolnego państwa jest gospodarstwo rodzinne. Zasada ta nie narusza postanowień art. 21, 22. Kategoria gospodarstwa rodzinnego będąca podstawą ustroju rolnego państwa nie może być traktowana jako naruszająca własność i prawo dziedziczenia oraz wolność działalności gospodarczej. W doktrynie wskazuje się, że relacja między powołanymi przepisami nie została ukształtowana na zasadzie lex specialis art. 23 względem art. 21, 22 Konstytucji RP ${ }^{23}$. Reguły kształtowania ustroju rolnego państwa nie mogą zatem wyłączać ochrony wartości w postaci własności i prawa dziedziczenia, ale także wolności działalności gospodarczej. Mogą natomiast modyfikować zakres ochrony podstawowych kategorii z uwagi na kategorię gospodarstw rodzinnych.

Dokonując wykładni art. 23 Konstytucji RP, należy zwrócić uwagę na charakter norm zawartych w rozdziale I Konstytucji

22 Por. chociażby A. Germano, Manuale di diritto agrario, Torino 2010.

23 Por. J. Ciapała, Konstytucyjna wolność działalności gospodarczej w Rzeczypospolitej Polskiej, Szczecin 2009, s. 153. 
RP zatytułowanym Rzeczpospolita. Rozdział ten zawiera bowiem zasady ustroju państwa. Są to specyficzne normy konstytucji o wysokim stopniu ogólności ${ }^{24}$. Zakodowane w nich zostały ponadto wartości, którymi powinien kierować się ustawodawca wcielając w życie konstytucyjne zasady. Stosowanie konstytucji w tym przypadku będzie polegało na wyważeniu wartości zakodowanych w zasadach i wyważeniu wszystkich wartości w możliwie jak najwyższym stopniu. Ustrojodawca może wskazywać pewien sposób rozstrzygania konfliktu wartości ${ }^{25}$. W zakresie art. 23 twórcy ustawy zasadniczej wskazali, które wartości należy wziąć pod uwagę przy ustawowym kształtowaniu ustroju rolnego. Wolność działalności gospodarczej oraz własność i prawo dziedziczenia nie mogą być postrzegane jako ograniczające preferencje na rzecz gospodarstwa rodzinnego. Wartości te powinny być uwzględniane łącznie (harmonizowane) przy kształtowaniu ustroju rolnego państwa ${ }^{26}$. Żadna z nich nie powinna ustępować innym. Konstatacja ta związana jest z szerszą konstytucyjną kategorią spójności podstaw społecznej gospodarki rynkowej27. Wartość w postaci gospodarstwa rodzinnego jako podstawy ustroju rolnego państwa nie powinna podlegać aksjologicznej hierarchizacji na niższej pozycji w odniesieniu do pozostałych wartości wskazanych przez ustrojodawcę. W związku z tym legislatywa powinna uwzględniać łącznie wskazane wartości.

Treść art. 23 powinna być rozumiana jako wskazująca konkretne wartości do wyważenia. Nie może być zaś traktowana jako uzasadniająca preferencję i nadrzędność wolności działalności gospodarczej wynikającej z art. 22 Konstytucji $\mathrm{RP}^{28}$. W ramach specyficznego rodzaju działalności gospodarczej, jakim jest działalność rolnicza, preferencja powinna dotyczyć gospodarstw rodzinnych. Stanowią one odrębną grupę od go-

24 Por. J. Galster, Propedeutyka wiedzy o konstytucji, w: Prawo konstytucyjne, red. Z. Witkowski, A. Bień-Kacała, Toruń 2015, s. 57-58.

25 Por. J. Galster, Propedeutyka wiedzy o konstytucji, w: Prawo konstytucyjne, red. Z. Witkowski, Toruń 2013, s. 58.

26 Por. L. Garlicki, op. cit., s. 6.

27 Por. K. Strzyczkowski, op. cit., s. 19-20.

28 Por. J. Ciapała, op. cit., s. 156-157. 
spodarstw towarowych opartych na pracy najemnej prowadzących działalność gospodarczą o rolniczym profilu. Jednakowa pozycja tych dwóch typów gospodarstw niweczy wartość konstytucyjną $\mathrm{w}$ postaci gospodarstw rodzinnych. Poza tym Trybunał Konstytucyjny wskazał w Wyroku z dnia 31 stycznia $2001 \mathrm{r}$. (P 4/99), że wolność ta może podlegać ograniczeniom wskazanym w ustawie z uwagi na ważny interes publiczny. Wartość $\mathrm{w}$ postaci kształtowania ustroju rolnego $\mathrm{w}$ oparciu o gospodarstwo rodzinne jest identyfikowana właśnie poprzez ważny interes publiczny.

$\mathrm{W}$ ramach relacji $\mathrm{z}$ art. 21 Konstytucji $\mathrm{RP}$ wskazuje się, że preferencja $\mathrm{w}$ zakresie ochrony powinna zostać ustalona na rzecz własności. Z drugiej jednak strony zauważa się, że prawo własności gospodarstwa rodzinnego powinno być traktowane przynajmniej na równi z innymi rodzajami własności ${ }^{29}$. Rzeczpospolita Polska powinna chronić każdą własność w równym stopniu, nie oznacza to natomiast jednakowego traktowania wszystkich kategorii w ramach konstytucyjnego pojęcia własności. Szczególne traktowanie jednego z rodzajów własności nie może natomiast prowadzić do pozbawienia własności innego rodzaju.

W kontekście wskazanych istotnych wartości konstytucyjnych kategoria gospodarstwa rodzinnego nie może wykluczać innych rodzajów własności ani prowadzenia działalności gospodarczej w rolnictwie. Gospodarstwo rodzinne jest natomiast wartością, która powinna być przez ustawodawcę preferowana $\mathrm{w}$ ramach ustroju rolnego. Jednakowe traktowanie innych rodzajów własności i działalności gospodarczej może być podstawą do identyfikowania dyskryminacji gospodarstw rolnych. Jednakowe bowiem potraktowanie gospodarstw rodzinnych oraz tych, które zajmują się produkcją rolną (towarową) na wielką skalę prowadzić może zwłaszcza do ograniczenia zasady konkurencji. W ramach społecznej gospodarki rynkowej jest to podstawowa wartość realizacji założeń konstytucyjnych ${ }^{30}$. Przy czym zauważa się istotny związek między konkurencją a ochro-

30 Por. K. Strzyczkowski, op. cit., s. 29-32. 
ną konsumentów, przede wszystkim w postaci odbiorców produktów żywnościowych czy zdolnością dostosowania się do potrzeb odbiorców. Ochrona dobra wspólnego stanowi legitymację dla państwa do podejmowania działań zmierzających do przeciwdziałania ograniczeniu konkurencji bądź ograniczeniu konkurencyjnej pozycji podmiotów gospodarczych. W tych kategoriach rozpatrywać należy konieczność ustalenia ustawowych preferencji na rzecz gospodarstw rodzinnych.

Wyważenie interesujących nas wartości musi więc uwzględniać kategorię równości oraz relację równości i własności. Istotnym kontekstem będzie w tym przypadku Wyrok TK z dnia 18 stycznia 2011 r. (P 44/08). Trybunał ustalił w nim treść normatywną art. 32 ust. 1, ale też art. 64 ust. 2 Konstytucji RP. Zgodnie z treścią uzasadnienia należy zauważyć, że rozumienie zasady równości ma w orzecznictwie Trybunału Konstytucyjnego jednoznaczną treść. Oznacza ono w szczególności nakaz jednakowego traktowania podmiotów prawa w obrębie określonej klasy (kategorii). Wszystkie podmioty prawa charakteryzujące się $\mathrm{W}$ równym stopniu daną cechą istotną powinny być traktowane równo, a więc według jednakowej miary, bez zróżnicowań zarówno dyskryminujących, jak i faworyzujących ${ }^{31}$.

W orzecznictwie Trybunału wskazuje się na ścisłe powiązania treści normatywnych art. 32, a w szczególności art. 32 ust. 1, z art. 64 ust. 2 Konstytucji. W Wyroku z dnia 17 marca 2008 r. (K 32/05) Trybunał wyjaśnił, że równa ochrona praw majątkowych jest jednym ze szczegółowych odniesień ogólnej zasady równości. W związku z tym art. 64 ust. 2 Konstytucji RP powinien być interpretowany w zgodzie z art. 32 Konstytucji RP, ponieważ zapewnienie równej dla wszystkich ochrony prawnej jest elementem równego traktowania przez władze publiczne. Istotą normatywnego sensu art. 64 ust. 2 Konstytucji RP jest wynikająca z tego przepisu zasada, że ochrona własności i innych praw majątkowych nie powinna być, w obrębie każdego z praw

31 Sąd konstytucyjny wskazał orzeczenia z: dnia 12 grudnia 1994 r., K 3/94 i dnia 23 października 1995 r., K 4/95 oraz 3 września 1996 r., K 10/96; Wyroki z: dnia 5 listopada 1997 r., K 22/97; dnia 18 stycznia 2000 r., K 17/99. 
majątkowych, różnicowana $\mathrm{z}$ uwagi na charakter podmiotu prawa. Ale zasada „równej dla wszystkich” ochrony prawnej własności i innych praw majątkowych może podlegać dalszemu wartościowaniu i w konsekwencji gradacji, gdyż art. 64 ust. 2 Konstytucji RP winien być odczytywany w kontekście innych przepisów konstytucyjnych, a równość ochrony prawnej w obrębie określonej kategorii jurydycznej (np. danego typu prawa podmiotowego bez względu na jego podmiot) nie może być absolutyzowana i traktowana jako cel sam w sobie, co podkreślił Trybunał w Wyroku z dnia 28 października 2003 r. (P 3/03). Jeśli zatem można wykazać, że zróżnicowanie ochrony znajduje oparcie w argumentacji w sprawie relewantności, proporcjonalności, powiązania z innymi normami, zasadami lub wartościami konstytucyjnymi to zróżnicowanie takie staje się dopuszczalne. $\mathrm{Z}$ taką sytuacją mamy do czynienia w odniesieniu do gospodarstw rolnych. Rodzinny charakter przesądza w tym kontekście uzasadnienie różnicowania podmiotów, a nawet można pójść dalej i opowiadać się za koniecznością stosowania preferencyjnych rozwiązań w odniesieniu do tej kategorii własności.

W związku z konstytucyjną rolą gospodarstw rodzinnych należy zauważyć ponadto, że regulacje prawne nie powinny utrudniać ich funkcjonowania poprzez preferencje dla gospodarstw innego typu. W tym kontekście wątpliwe powinno być stosowanie tych samych preferencji dla grupy gospodarstw rodzinnych oraz innych gospodarstw. Takie równe traktowanie może być bowiem dyskryminujące dla grupy gospodarstw rodzinnych. Wskazana już została interpretacja zasady równości. W jej wykładni założyć należy jednocześnie konieczność różnego traktowania podmiotów różnych, tj. podmiotów nieposiadających wspólnej cechy istotnej. Równość wobec prawa to zasadność wyboru takiego, a nie innego kryterium różnicowania. Oceniając regulację prawną z punktu widzenia zasady równości, należy w pierwszej kolejności rozważyć, czy można wskazać wspólną cechę istotną uzasadniającą równe traktowanie podmiotów prawa, biorąc pod uwagę treść i cel danej regulacji prawnej.

W sytuacji, w której charakter wykonywanej działalności 3/2015 (rolniczej) zostałby uznany za cechę relewantną istotny także, 
z punktu widzenia art. 23 Konstytucji RP, powinien być rodzaj podmiotu wykonującego taką działalność. Mielibyśmy wówczas do czynienia z kategorią podmiotów podobnych. Co do zasady powinny być one traktowane równo. Niekiedy jednak nierówne traktowanie podmiotów podobnych może oznaczać dyskryminację $e^{32}$. Konieczna jest bowiem w takim przypadku ocena kryterium, na podstawie którego dokonano zróżnicowania, bowiem wszelkie odstępstwo od nakazu równego traktowania podmiotów podobnych musi zawsze znajdować podstawę w przekonujących argumentach. Kryterium to winno pozostawać w związku z innymi wartościami, zasadami czy normami konstytucyjnymi, uzasadniającymi odmienne traktowanie podmiotów podobnych. Jeśli kryterium to nie służy urzeczywistnianiu zasad lub konstytucyjnych wartości, różnicowanie w sytuacji prawnej podmiotów powinno zostać uznane za niekonstytucyjną dyskryminację (uprzywilejowanie). W interesującej nas sytuacji oczywiście kryterium rozróżnienia będzie szczególny konstytucyjny status gospodarstw rodzinnych i ten status uzasadnia uprzywilejowanie w ramach działalności rolniczej dla grupy gospodarstw rodzinnych.

Wskazując inne jeszcze wartości, jakie powinny być wzięte pod uwagę należy przywołać wynikające z art. 2 Konstytucji RP prawo do sprawiedliwego traktowania ${ }^{33}$. Traktowanie jest sprawiedliwe, jeśli nie będzie arbitralne, ale też będzie odpowiadało standardom państwa prawa. Sprawiedliwość społeczna bowiem mieści w sobie zakaz arbitralności państwa, dopuszczając różnicowanie poszczególnych jednostek, ale tylko w odpowiedniej relacji do różnic w ich sytuacji ${ }^{34}$. W interesującej nas kwestii równe potraktowanie podmiotów wykonujących działalność rolniczą prowadzi do faktycznej nierówności i gorszego

32 Zob. np. Wyrok z dnia 15 października 2001 r., K 12/01 czy Wyrok z dnia 12 maja 1998 r., U 17/97.

33 Por. S. Oliwniak, Art. 2 Konstytucji RP z dnia 2 kwietnia 1997 r. jako wzorzec kontroli konstytucyjności w skardze konstytucyjnej, w: Państwo prawa, parlamentaryzm, sq̨downictwo konstytucyjna, red. A. Jamróz, Białystok 2012, s. 247-248.

34 Por. W. Sokolewicz, Uwagi do art. 2 Konstytucji, w: Konstytucja Rzeczypospolitej Polskiej. Komentarz, t. 5, red. L. Garlicki, Warszawa 2007, s 62. 
traktowania gospodarstw rodzinnych. Z reguły gospodarstwa te są mniejsze od gospodarstw towarowych (prowadzonych co do zasady przez inny podmiot niż rodzina), a w konsekwencji posiadają mniejszą siłę nabywczą w odniesieniu do terenów rolniczych. W takich warunkach, bez odpowiednich mechanizmów ustawowych konstytucyjne założenie oparcia ustroju rolnego na gospodarstwach rodzinnych nie może zostać zrealizowane. Uzasadnia to jednocześnie stosowanie preferencji na rzecz gospodarstw określonych w art. 23 Konstytucji RP, nie zaś podmiotów innego typu.

Należy także odwołać się do orzecznictwa Trybunału Konstytucyjnego w tym zakresie. W Wyroku z dnia 26 października 2010 r. (K 58/07) organ ten wskazał, że w ujęciu konstytucyjnym sprawiedliwość społeczna jest celem, który demokratyczne państwo prawne ma urzeczywistniać. Trybunał wskazał także, że nierówność może dotyczyć obciążenia daniną publiczną w zakresie zdolności opłatowej rolników lub ich domowników, za których składki na ubezpieczenie zdrowotne finansuje na rzecz KRUS budżet państwa, bez względu na wysokość osiąganych dochodów. Grupa rolników nie jest bowiem grupą jednorodną, mającą wspólną cechę istotną, uzasadniającą ich jednolite traktowanie przy prawnym uregulowaniu ich obowiązku opłatowego w zakresie ubezpieczenia zdrowotnego. Takiej cechy, istotnej biorąc pod uwagę powszechność opodatkowania (art. 84 Konstytucji RP) i równość opodatkowania (art. 32 ust. 1 w związku z art. 2 Konstytucji RP), co łącznie składa się na pojęcie sprawiedliwości podatkowej, należy upatrywać w sytuacji ekonomicznej poszczególnych rolników, decydującej o ich zdolności podatkowej (opłatowej). Z tego punktu widzenia populacja rolników prowadzących działalność gospodarczą w zakresie rolnictwa jest dzisiaj (w przeciwieństwie do sytuacji w 1991 r.) bardzo zróżnicowana. Obejmuje dużą liczbę osób o dochodach nieodbiegających od poziomu dochodów osób będących podatnikami podatku dochodowego od osób fizycznych, jednostki o bardzo wysokich dochodach oraz nadal pokaźną liczbę osób prowadzących gospodarstwa rolne o bardzo niskiej wydajności i dochodowości. Stanowi to potwierdzenie tezy o konieczności 3/2015 różnego traktowania $\mathrm{z}$ uwagi na treść art. 23 Konstytucji RP 
gospodarstw rodzinnych czy takich, które nimi nie są. Tym bardziej, że regułą podstawową jest, wynikająca z art. 84 Konstytucji RP, powszechność obciążenia daniną publiczną ${ }^{35}$. Oznacza ona, że daniny powinny być nakładane w równym stopniu na wszystkie podmioty funkcjonujące w państwie, a wszelkie odstępstwa od niej muszą być uzasadnione odpowiednią wartością konstytucyjną (np. w postaci gospodarstw rodzinnych).

Logiczne i konstytucyjnie uzasadnione wydaje się dodatkowo powiązanie kategorii gospodarstwa rodzinnego z ochroną rodziny przewidzianą $\mathrm{w}$ Konstytucji RP z $1997 \mathrm{r} .{ }^{36}$ Rodzina jest wartością chronioną w art. 18 ustawy zasadniczej. Na tle tego przepisu Trybunał Konstytucyjny wskazuje, że przez pojęcie rodziny rozumieć należy pewną skomplikowaną rzeczywistość społeczną będącą sumą stosunków łączących przede wszystkim rodziców, dzieci (Orzeczenie TK z dnia 28 maja 1997 r., K 26/96) oraz trwały związek mężczyzny i kobiety nakierowany na macierzyństwo, jak również odpowiedzialne rodzicielstwo (Wyrok TK z dnia 12 kwietnia 2011 r., SK 62/08). Odpowiada to rozumieniu tego pojęcia $\mathrm{w}$ nauce prawa ${ }^{37}$. Dodatkową wartością, która powinna zostać uwzględniona przez ustawodawcę przy kształtowaniu ustroju rolnego jest tak postrzegana rodzina. W tym kontekście należy wskazać, że podmiotem zbiorowym (wspólnotą jednostek) prowadzącym gospodarstwo rodzinne powinna być właśnie rodzina. Z ustrojowego punktu widzenia ma więc znaczenie, kto prowadzi gospodarstwo, stanowiące podstawę ustroju rolnego.

W Wyroku z dnia 9 listopada 2010 r. (SK 10/08) Trybunał Konstytucyjny wskazał ponadto, że art. 18 Konstytucji ma charakter normy programowej. Przesądza to konieczność traktowania go jako zawierającego wskazanie celów działania organów władzy państwowej. Powinny być one nakierowane na ochronę

35 Por. T. Dębowska-Romanowska, Prawo finansowe. Czesść konstytucyjna wraz z częścia ogólna, Warszawa 2010, s. 123-124; A. Bień-Kacała, Zasada władztwa daninowego w Konstytucji RP z 1997 r., Toruń 2005, s. 38-39.

36 Por. J. Galster, T. Staranowicz, op. cit., s. 86.

37 Por. T. Smyczyński, Rodzina i prawo rodzinne $w$ świetle nowej Konstytucji, „Państwo i Prawo” 1997, nr 11-12, s. 185. 
między innymi rodziny. Ma to oczywiste przełożenie na ochronę gospodarstw rodzinnych w ramach kształtowania ustroju rolnego. Pojęcie rodziny jedynie pośrednio możemy identyfikować $\mathrm{z}$ instytucją małżeństwa, ważniejsze $\mathrm{w}$ tym przypadku powinny okazać się więzy krwi czy też więź emocjonalna podbudowana więzią prawną. W powiązaniu natomiast $\mathrm{z}$ kategorią wypływającą z art. 23 Konstytucji RP należy wskazać, że ochrona rodziny zostaje tu wzmocniona poprzez ustrój rolny i szczególną rolę gospodarstwa rodzinnego, a zatem prowadzonego przez rodzinę. Argumentację tę wzmacnia traktowanie rodziny w kategoriach wspólnoty jednostek, której uprawnienia powinny być umacniane zgodnie z konstytucyjną kategorią pomocniczości. Poprzez zasadę pomocniczości państwo bowiem powinno umacniać uprawnienia jednostek oraz ich wspólnot. Podstawową wspólnotą jest w tym przypadku rodzina ${ }^{38}$. Władze publiczne powinny zatem stworzyć odpowiednie (w tym ustawowe) rozwiązania sprzyjające nie tylko samodzielnej egzystencji gospodarstw rodzinnych, ale również takiej ich pozycji, która zapewni produkcję rolną dla całego społeczeństwa oraz odpowiedni dochód budżetowy.

Nie bez znaczenia w tym zakresie jest także wynikające $\mathrm{z}$ art. 5 Konstytucji RP zadanie państwa w zakresie strzeżenia dziedzictwa narodowego. Nie budzi wątpliwości, że podstawowe wartości narodowe kultywowane są przede wszystkim w ramach rodziny, małych wspólnot jednostek, zwłaszcza na wsi. Ochrona gospodarstw rodzinnych ma także związek z zachowaniem dziedzictwa narodowego postrzeganego jako element dobra wspólnego. Zmiana struktury rolnej państwa przez zastąpienie gospodarstw rodzinnych gospodarstwami towarowymi prowadzonymi przez osoby prawne spowoduje także rozerwanie więzów tych naturalnych wspólnot wiejskich, a w konsekwencji obniży poziom zachowania zwyczajów regionalnych i narodowych.

W zakończeniu uwag na temat konstytucyjnej kategorii gospodarstw rodzinnych warto wskazać, że oparcie ustroju rol-

38 Por. M. Dobrowolski, Status prawny rodziny $w$ świetle nowej Konstytucji Rzeczypospolitej Polskiej, „Przegląd Sejmowy” 1999, nr 4, s. 32. 
nego na kategorii gospodarstwa rodzinnego nie oznacza zakazu funkcjonowania innych typów gospodarstw rolnych ${ }^{39}$. Nie powinna to być natomiast alternatywna forma gospodarowania w zakresie działalności rolniczej. Trzon gospodarstw powinny stanowić gospodarstwa rodzinne, a przywileje powinny być ustanawiane na ich właśnie rzecz. Znaczenie art. 23 Konstytucji RP przekłada się bowiem na odpowiednie ukształtowanie regulacji gospodarczych i finansowych preferujących gospodarstwo rodzinne ${ }^{40}$. Chodzi zwłaszcza o stosowanie ulg podatkowych, finansowych czy kredytowych. Nie chodzi przy tym o regulacje wyłącznie „pomocowe”. Ustrój rolny powinien opierać się na kategorii gospodarstw rodzinnych, co wymaga od ustawodawcy takiego kształtowania rozwiązań prawnych, aby gospodarstwa tego typu mogły rozwijać się $\mathrm{w}$ pierwszym rzędzie. Jeśli rozwiązania ustawowe nie zawierają dostatecznych instrumentów, powinny zostać dostosowane do aktualnych warunków społeczno-gospodarczych. Nastąpił bowiem rozdźwięk między stanem projektowanym w konstytucji a rzeczywistością społeczno-gospodarczą. Artykuł 23 Konstytucji RP jest bowiem przepisem dynamicznym wymagającym stałego dostosowywania do zmieniającego się kontekstu ekonomicznego.

\section{BIBLIOGRAFIA}

Bień-Kacała A., Zasada władztwa daninowego $w$ Konstytucji $R P$ z 1997 r., Toruń 2005.

Boć J., Konstytucje Rzeczypospolitej oraz komentarz do Konstytucji RP z 1997 roku, Wrocław 1998.

Ciapała J., Konstytucyjna wolność działalności gospodarczej w Rzeczypospolitej Polskiej, Szczecin 2009.

Dębowska-Romanowska T., Prawo finansowe. Część konstytucyjna wraz z częścia ogólną, Warszawa 2010.

Dobrowolski M., Status prawny rodziny $w$ świetle nowej Konstytucji Rzeczypospolitej Polskiej, „Przegląd Sejmowy” 1999, nr 4.

39 Por. L. Garlicki, op. cit., s. 3-4.

40 Por. A. Lichorowicz, Konstytucyjne podstawy..., s. 119, 224. 
Domańska A., Konstytucyjne podstawy ustroju gospodarczego Polski, Warszawa 2001.

Galster J., Propedeutyka wiedzy o konstytucji, w: Prawo konstytucyjne, red. Z. Witkowski, A. Bień-Kacała, Toruń 2015.

Galster J., Propedeutyka wiedzy o konstytucji, w: Prawo konstytucyjne, red. Z. Witkowski, Toruń 2013.

Galster J., Staranowicz T., Konstytucyjne pojęcie rodzinnego gospodarstwa rolnego i jego ustawowa deformacja. Studium jednego przypadku, „Journal of Modern Science” 2012, vol. 13, nr 2.

Garlicki L., Art. 23, w: Konstytucja Rzeczypospolitej Polskiej. Komentarz, red. L. Garlicki, t. 4, Warszawa 2005.

Germano A., Manuale di diritto agrario, Torino 2010.

Jeżyńska B., Współczesne funkcje gospodarstw rodzinnych. Zagadnienia prawne, Opinie i Ekspertyzy OE-214, Kancelaria Senatu styczeń 2014.

Kidyba A., Handlowe spótki osobowe, Warszawa 2013.

Lichorowicz A., Konstytucyjne podstawy ustroju rolnego Rzeczypospolitej $w$ świetle artykutu 23 Konstytucji, w: Konstytucyjne podstawy systemu źródeł prawa, red. M. Wyrzykowski, Warszawa 2001.

Lichorowicz A., Status prawny gospodarstw rodzinnych $w$ ustawodawstwie krajów Europy Zachodniej, Białystok 2000.

Łobos-Kotowska D., Gospodarstwo rodzinne. Prawne formy organizacji, Sosnowiec 2006.

Oliwniak S., Art. 2 Konstytucji RP z dnia 2 kwietnia 1997 r. jako wzorzec kontroli konstytucyjności w skardze konstytucyjnej, w: Państwo prawa, parlamentaryzm, sądownictwo konstytucyjna, red. A. Jamróz, Białystok 2012.

Pawłowski A., Aspekty podmiotowe i przedmiotowe ustroju rolnego, „Gdańskie Studia Prawnicze” 2014, t. XXXI.

Prawo spótek, red. A. Kidyba, Warszawa 2014.

Rakoczy B., Ochrona środowiska w procesie produkcji rolnej, red. A. Stelmachowski, Prawo rolne, Warszawa 2009.

Rakoczy B., Problemy ochrony środowiska $w$ procesie produkcji rolnej, „Prawo i środowisko” 2002, nr 4.

Rakoczy B., Publiczne prawo gospodarki rolnej i przetwórczej, w: Publiczne prawo gospodarcze, red. A. Powałowski, Warszawa 2012.

Rudy M., Wstęp do prawa sanitarnego i weterynaryjnego, Wrocław 2010.

Smyczyński T., Rodzina i prawo rodzinne $w$ świetle nowej Konstytucji, „Państwo i Prawo” 1997, nr 11-12. 
Sokolewicz W., Uwagi do art. 2 Konstytucji, w: Konstytucja Rzeczypospolitej Polskiej. Komentarz, t. 5, red. L. Garlicki, Warszawa 2007.

Strzyczkowski K., Konstytucyjna zasada społecznej gospodarki rynkowej jako podstawa tworzenia i stosowania prawa, w: Zasady ustroju spotecznego i gospodarczego $w$ procesie stosowania Konstytucji, red. C. Kosikowski, Warszawa 2005.

Winczorek P., Komentarz do Konstytucji Rzeczypospolitej Polskiej z dnia 2 kwietnia 1997 r., Warszawa 2000.

Kontakt e-mail:

kpos@umk.pl

abien@law.umk.pl 